\title{
The influence of ice marginal setting on early Holocene retreat rates in central West Greenland
}

\author{
SAMUEL E. KELLEY, ${ }^{1,2} *$ JASON P. BRINER ${ }^{1}$ and SUSAN R. H. ZIMMERMAN ${ }^{3}$ \\ ${ }^{1}$ Geology Department, University at Buffalo, NY, USA \\ ${ }^{2}$ Earth and Environmental Sciences, University of Waterloo, 200 University Ave. W, Waterloo, Ontario, Canada N2L 3G1 \\ ${ }^{3}$ Center for AMS, Lawrence Livermore National Laboratory, CA, USA
}

Received 3 December 2014; Revised 25 February 2015; Accepted 9 March 2015

\begin{abstract}
Ice sheet reconstructions from diverse ice margin settings, spanning multiple millennia, are needed to assess the reaction of the Greenland Ice Sheet (GrlS) to millennial-scale climatic forcing and to place historical records in a longer-term context. Here we present 18 new cosmogenic ${ }^{10} \mathrm{Be}$ exposure ages and five new radiocarbon ages that constrain the early Holocene retreat of the GrIS in the Disko Bugt region in both a marine and a land-based setting. Results indicate similar rates of early Holocene retreat of $\sim 40-50 \mathrm{~m} \mathrm{a}^{-1}$ from transects in Torsukattak fjord (marine setting) and the Naternaq area (land-based setting). We compile seven previously published chronologies of deglaciation from West Greenland, which yield early Holocene retreat rates ranging from 10 to $65 \mathrm{~m} \mathrm{a}^{-1}$, similar to those determined for our two study areas. This work demonstrates that when averaged on millennial timescales, retreat rates were remarkably similar along the western GrlS margin. Furthermore, the retreat rates calculated here demonstrate that terrestrial sectors of ice sheets can retreat at net rates comparable to their marine counterparts. Copyright (C) 2015 John Wiley \& Sons, Ltd.
\end{abstract}

KEYWORDS: ${ }^{10}$ Be exposure dating; Greenland Ice Sheet; Holocene.

\section{Introduction}

Scrutiny of recent Greenland Ice Sheet (GrlS) change has provided valuable insight into its response to past and ongoing climate change (e.g. Zwally et al., 2002; Holland et al., 2008; Khan et al., 2014). The historical record reveals a complex picture of GrIS behavior over the past two centuries (Weidick, 1968, 1994; Bjørk et al., 2012; Kjær et al., 2012). This complex picture highlights the significant variability exhibited in ice margin change along the periphery of the GrlS (Moon and Joughin, 2008; Bjørk et al., 2012). For example, marine-terminating glaciers in West Greenland have retreated an order of magnitude more than landterminating glaciers during the 19th-21st centuries, probably due to differences in their sensitivity to climate forcing (Weidick, 1994; Kelley et al., 2012). However, it is challenging to identify the influence of climate change on ice margin change in the brief observational record, due to influential ice sheet dynamics in some sectors. Reconstructions of ice margin fluctuations spanning the Holocene can be used to provide a longer term perspective on the response of the GrIS to a warming climate.

Our knowledge of fluctuations of the GrlS during the Holocene has expanded in recent years (Möller et al., 2010; Long et al., 2011; Levy et al., 2012; Briner et al., 2014; Dyke et al., 2014). This is especially true along the western GrlS margin where new chronologies provide detailed snapshots of Holocene ice margin fluctuations (e.g. Young et al., 2011a 2013a; Levy et al., 2012; Kelley et al., 2013), as well as studies that track movement of the ice margin over many millennia (Weidick and Bennike, 2007; Weidick et al., 2012; Cofaigh et al., 2013; Roberts et al., 2013; Lane et al., 2014; Larsen et al., 2014). Despite these records advancing our knowledge of past GrIS ice margin changes, they are dominated by marineterminating outlet glaciers, and have not focused on how ice margins behave in varying settings during changes in climate.

Here, we constrain the timing and rate of early Holocene retreat in two contrasting glacial systems in West Greenland -

${ }^{*}$ Correspondence: Samuel E. Kelley, ${ }^{2}$ Earth and Environmental Sciences, as above. E-mail: samuel.kelley@uwaterloo.ca one marine-based and one land-based system - using 18 new ${ }^{10} \mathrm{Be}$ ages and five new radiocarbon ages. We use our new chronology to compare the behavior of marine- and landbased glacier systems during early Holocene warming. This comparison allows us to evaluate similarities and differences in the retreat of these early Holocene glacier systems in the context of modern observations of GrlS outlet glacier behavior.

\section{Setting}

\section{The Disko Bugt region}

We selected two paleo-glacier systems in the Disko Bugt region, central West Greenland, to build chronologies detailing early Holocene retreat. The Torsukattak fjord (northern Disko Bugt) and Nordenskiöld Gletscher (southern Disko Bugt) study areas present two contrasting paleo-glacier systems, one marine-based and one land-based (Fig. 1). We reconstruct the timing and rate of retreat at each site in response to early Holocene warming ( 11.7-8.2 ka), estimated from ice cores to be $\sim 6^{\circ} \mathrm{C}$ in central Greenland (Vinther et al., 2009). The two study areas presently experience similar climatic conditions (Box, 2002), and are separated by a distance of $\sim 175 \mathrm{~km}$.

Torsukattak fjord is located in northernmost Disko Bugt, south of the peninsula of Nuussuaq (Figs 1 and 2A). The GrlS presently drains into the fjord via Sermeq Kujalleq and Sermeq Avannarleq, major outlet glaciers separated by a nunatak. The region is characterized by high relief, with water depths exceeding $500 \mathrm{~m}$ (Rignot et al., 2010), and fjord walls that rise to $>600 \mathrm{~m}$ above sea level (asl). The fjord connects to Baffin Bay via Disko Bugt to the south-west and through the Vaigat Strait to the north-west. At present, oceanographic circulation at the mouth of Torsukattak fjord is influenced by a limb of the warm West Greenland Current (WGC), which flows from the south-west through Disko Bugt, exiting through Vaigat Strait (Seidenkrantz et al., 2008). Warm water from the WGC penetrates into Torsukattak fjord, causing basal melting along glacier margins at the fjord head (Rignot et al., 2010). 


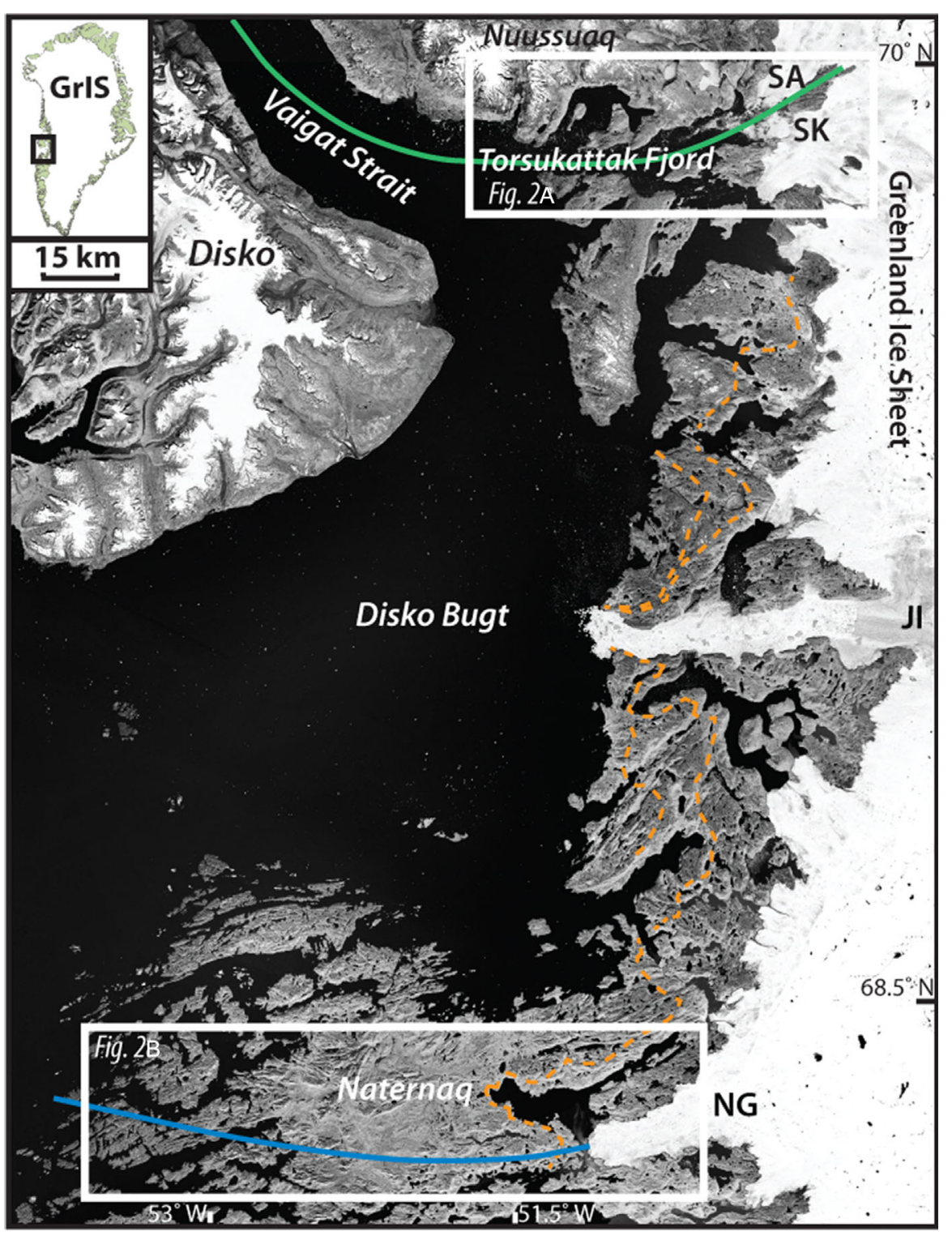

Figure 1. The Disko Bugt region showing the location of the two study areas (white boxes): SA, Sermeq Avannarleq; SK, Sermeq Kujalleq; II, Jakobshavn Isbræ; NG, Nordenskiöld Gletscher. Solid lines denote transect locations used in Fig. 4 and the orange dotted line marks the Fjord Stade Moraines. Inset map shows the location of Disko Bugt (black box) in Greenland. (For interpretation of the references to color in this figure legend, the reader is referred to the online version of this article.) This figure is available in colour online at wileyonlinelibrary.com.
The Naternaq study area is located along the 90-km-wide ice-free corridor that separates Baffin Bay from the GrIS margin at Nordenskiöld Gletscher (Fig. 1). The Naternaq area is characterized by rounded bedrock hills reaching $\sim 450 \mathrm{~m}$ asl. Low-lying areas are filled with glaciomarine sediments and till (Weidick, 1974). Limited ice flow indicators suggest that flow was roughly east-to-west across the region, with a possible change in flow occurring late during deglaciation, routing ice along a more north-easterly flowline into Disko Bugt (Weidick, 1974). A belt of north-south-trending moraines crosses the field area about $5 \mathrm{~km}$ west and $10 \mathrm{~km}$ north of Nordenskiöld Gletscher (Fig. 2B), and has been mapped as part of the Fjord Stade Moraine belt (Weidick, 1968).

\section{Glacial history}

\section{Torsukattak fjord}

South-west of the study area, the deglaciation of the Disko Bugt region of West Greenland initiated on the continental shelf by $13900 \pm 100 \mathrm{cal}$ a BP, perhaps reaching as far east as Disko Island by $12.2 \pm 0.6$ ka [Rinterknecht et al., 2014; all cosmogenic-nuclide exposure ages are calculated using the Arctic production rate (Young et al., 2013b) with the Lal/ Stone scaling scheme (Lal, 1991; Stone, 2000); all radiocarbon ages are presented in calibrated years as the mean \pm half of the one-sigma age range; ages are calibrated using Calib version 7.0 (calib.qub.ac.uk/), with marine ages using the MarineCal13 and a $\Delta R$ of $140 \pm 25$ based on Lloyd et al. (2011) and terrestrial ages using the IntCal13 dataset], with a brief readvance at $12000 \pm 200 \mathrm{cal}$ a BP (Ó Cofaigh et al., 2013). Radiocarbon and ${ }^{10} \mathrm{Be}$ ages from the mouth of Disko Bugt place deglaciation at between 11 and $10 \mathrm{ka}(n=16$; Donner and Jungner, 1975; Frich and Ingólfsson, 1990; Ingólfsson et al., 1990; Long and Roberts, 2002; Long et al., 2003; Long et al., 2011; Kelley et al., 2013), with a radiocarbon date on foraminifera from a marine sediment core collected in inner Disko Bugt suggesting the area was ice-free by $10200 \pm 100 \mathrm{cal}$ a BP (Lloyd et al., 2005). Limited radiocarbon dating constrains eastward retreat of the GrIS in the Torsukattak fjord study area (Fig. 2A). A radiocarbon age from a bulk gyttja sample constrains deglaciation before $9920 \pm 220$ cal a BP south of the fjord mouth; a second radiocarbon age of $9930 \pm 230 \mathrm{cal}$ a BP from marine shells constrains deglaciation west of the fjord mouth (Tauber, 1960; Weidick, 1968; Long et al., 1999). Similar ages from eastern Disko place minimum constraints on deglaciation at $10060 \pm 180$ and $9650 \pm 160 \mathrm{cal}$ a BP based on bulk gyttja and shells, respectively (Ingólfsson et al., 1990). Weidick and Bennike (2007) infer that the Marrait moraine, dated elsewhere in Disko Bugt to 9.2 ka (Young et al., 2011b), 
Figure 2. (A) The Torsukattak (top), and (B) Naternaq (bottom) study areas showing the location of ${ }^{10} \mathrm{Be}$ (yellow circles) and radiocarbon ages (green squares) in thousands of years; ages in bold are from this study; ages in plain font are from previous work mentioned in the text. Bathymetric data are from Hogan et al. (2012). Orange dotted line in panel B marks the position of the Fjord Stade Moraines. SA, Sermeq Avannarleq; SK, Sermeq Kujalleq. (For interpretation of the references to color in this figure legend, the reader is referred to the online version of this article.) This figure is available in colour online at wileyonlinelibrary.com.

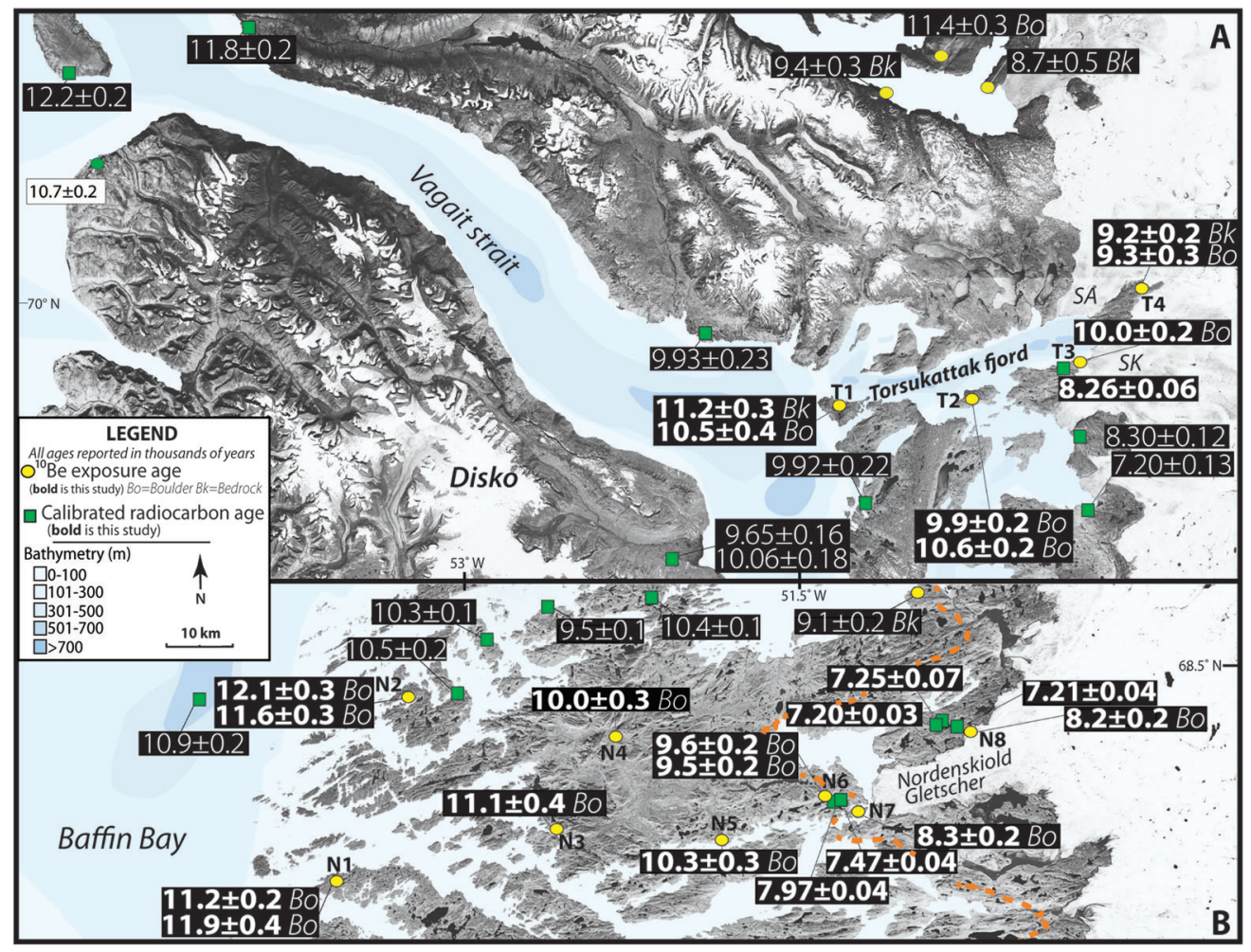

intersects the mouth of Torsukattak fjord. This may be corroborated by a marine geophysical study that suggests the ice margin may have paused there during retreat at $\sim 9.9 \mathrm{ka}$, followed by continuous recession up the fjord (Hogan et al., 2012). Radiocarbon ages related to deglaciation from the inner fjords of northern Disko Bugt are sparse, with a single minimum constraint on deglaciation, $\sim 15 \mathrm{~km}$ south of Torsukattak fjord, that places local deglaciation before $8300 \pm 120$ cal a BP (Ingólfsson et al., 1990).

\section{Naternaq}

Chronology pertaining to the early Holocene deglaciation of the Naternaq study area comes primarily from north and west of the field area (Fig. 2B). A minimum-limiting radiocarbon age from a bivalve collected in a marine sediment core in nearshore Baffin Bay, north-west of the study area, is 10 $900 \pm 200$ cal a BP (Quillmann et al., 2009; Jennings et al., 2014). Radiocarbon ages from the southern margin of Disko Bugt suggest deglaciation between 11 and $10 \mathrm{ka}$. For example, a basal date from bulk sediment collected in a lake sediment core places deglaciation in south-westernmost Disko Bugt before $10500 \pm 200 \mathrm{cal}$ a BP (Long and Roberts, 2002). Additional radiocarbon ages from bulk sediment in lake sediment cores collected farther east along the southern margin of Disko Bugt are $10400 \pm 100 \mathrm{cal}$ a BP (Long et al., 2003) and $10300 \pm 100$ cal a BP (Long and Roberts, 2002) and an age of $9500 \pm 200 \mathrm{cal}$ a BP on shells collected from a raised marine deposit (Donner and Jungner, 1975). ${ }^{10} \mathrm{Be}$ ages from south-western Disko Bugt are slightly older than the radiocarbon ages. A 5-km-long transect of ages, which decreases in age to the south, places retreat of ice out of Disko Bugt by $11.0 \pm 0.2 \mathrm{ka}$ at the northern point in the transect, $10.9 \pm 0.2 \mathrm{ka}$ at the middle of the transect and an average age of $10.4 \pm 0.2 \mathrm{ka}(n=2)$ at the southern end (Kelley et al., 2013). Closer to the present ice margin, $\sim 30 \mathrm{~km}$ north of Nordenskiöld Gletscher, a radiocarbon age from a bulk sediment sample $(9600 \pm 200 \mathrm{cal} \mathrm{a} \mathrm{BP})$ and ${ }^{10} \mathrm{Be}$ ages
$(9.2 \pm 0.1 \mathrm{ka} ; n=2)$ are in good agreement on the timing of ice retreat onto the mainland (Long and Roberts, 2002; Young et al., 2013a). Surficial mapping places the Fjord Stade moraines roughly parallel to, and $5-10 \mathrm{~km}$ beyond, the rightlateral and terminal margins of Nordenskiöld Gletscher (Weidick, 1968), indicating that the ice margin resided in that area between 9.3 and 8.2 ka (Young et al., 2013a). Finally, ${ }^{10} \mathrm{Be}$ ages from adjacent to the present ice margin $\sim 55 \mathrm{~km}$ to the north of Nordenskiöld Gletscher, suggest ice retreated behind the present ice margin by $7.0 \pm 0.1$ ka (Kelley et al., 2012).

\section{Methods}

We collected samples for ${ }^{10} \mathrm{Be}$ dating along two transects roughly perpendicular to the present ice margin, with one transect located along the southern margin of Torsukattak fjord and the second in the Naternaq region. We collected lake sediment cores from four lakes in the Naternaq study area to obtain basal radiocarbon dating constraints on deglaciation (see supporting Fig. S1; Fig. 2). Full details of ${ }^{10} \mathrm{Be}$ and radiocarbon dating methods are given in the supporting information (Appendix S1).

\section{Results}

\section{${ }^{10}$ Be dating}

\section{Torsukattak fjord}

Seven samples for ${ }^{10} \mathrm{Be}$ dating were collected from four locations on a west-east transect along the southern margin of Torsukattak fjord (Fig. 2A; Table 1). Two ${ }^{10} \mathrm{Be}$ ages from outer Torsukattak fjord (site T1) derived from bedrock and a boulder yield ages of $11.2 \pm 0.3$ and $10.5 \pm 0.4 \mathrm{ka}$, respectively, and average $10.9 \pm 0.5 \mathrm{ka}$ (all averages are mean \pm one SD). Two boulders from a mid-fjord location (site T2) yield ${ }^{10} \mathrm{Be}$ ages of $10.6 \pm 0.2$ and $9.9 \pm 0.2 \mathrm{ka}$, which average $10.3 \pm 0.5 \mathrm{ka}$. $\mathrm{A}{ }^{10} \mathrm{Be}$ age from about $2 \mathrm{~km}$ west of Sermeq 
Table 1. Sample information for ${ }^{10}$ Be ages.

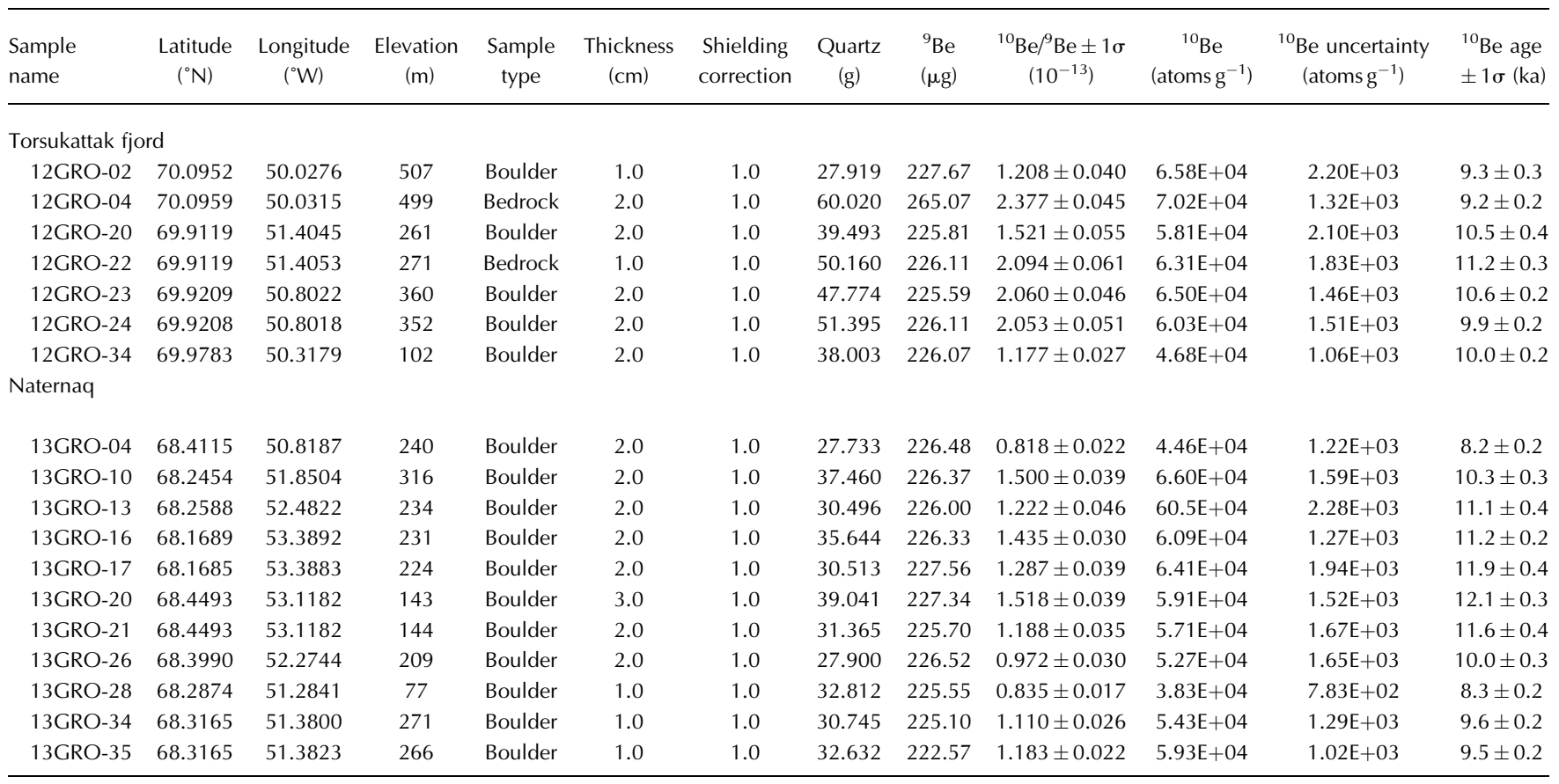

All samples were spiked with a $372.5 \mu \mathrm{gg}^{-1}{ }^{9}$ Be carrier; AMS results are standardized to 07KNSTD; ratios are blank-corrected, and shown at 1-sigma uncertainty.

Kujalleq (site T3) derived from bedrock yields an age of $10.0 \pm 0.2 \mathrm{ka}$. One bedrock sample and one boulder sample collected from the nunatak at the head of Torsukattak fjord (site T4) yield ages of $9.2 \pm 0.2$ and $9.3 \pm 0.3 \mathrm{ka}$, respectively, and average $9.3 \pm 0.1 \mathrm{ka}$.

\section{Naternaq}

Eleven boulder samples were collected from bedrock hills above local marine limit along a west-east transect from Baffin Bay to Nordenskiöld Gletscher (Fig. 2B; Table 1). Two samples collected from a hilltop on the Baffin Bay coastline (site N1) yield ages of $11.2 \pm 0.2$ and $11.9 \pm 0.4 \mathrm{ka}$ and average $11.6 \pm 0.5 \mathrm{ka}$. To the south, two samples collected at site N2, also on the Baffin Bay coastline, yield ages of $12.1 \pm 0.3$ and $11.6 \pm 0.3 \mathrm{ka}$ and average $11.9 \pm 0.4 \mathrm{ka}$. About $50 \mathrm{~km}$ east of the coast, a single boulder from site N3 yields an age of $11.1 \pm 0.4 \mathrm{ka}$. In central Naternaq a perched erratic boulder on a bedrock hilltop, site N4, yields an age of $10.0 \pm 0.3 \mathrm{ka}$. On the southern margin of the study area, $\sim 100 \mathrm{~km}$ east of the coast and $\sim 30 \mathrm{~km}$ west of the Nordenskiöld Gletscher terminus, an erratic at site N5 yields an age of $10.3 \pm 0.3 \mathrm{ka}$. Two boulder samples collected at site N6, $>1 \mathrm{~km}$ outboard of a flight of moraines mapped as the Fjord Stade Moraines and located about $5 \mathrm{~km}$ west of Nordenskiöld Gletscher, yield ages of $9.6 \pm 0.2$ and $9.5 \pm 0.2 \mathrm{ka}$ and average $9.5 \pm 0.1 \mathrm{ka}$ (Fig. 3). A boulder sample collected at site N7, $\sim 4 \mathrm{~km}$ inboard of the moraines and $\sim 4 \mathrm{~km}$ west of the Nordenskiöld Gletscher terminus, yields an age of $8.3 \pm 0.2 \mathrm{ka}$. The easternmost sample in our transect, collected $\sim 0.5 \mathrm{~km}$ from the present Nordenskiöld Gletscher margin (site N8) and inboard of the Fjord Stade Moraines, yields an age of $8.2 \pm 0.2 \mathrm{ka}$.

\section{Radiocarbon}

\section{Torsukattak fjord}

In Torsukattak fjord, raised marine deposits reach an elevation of $\sim 30 \mathrm{~m}$ asl. A radiocarbon age of $8260 \pm 60 \mathrm{cal}$ a BP was obtained from paired mollusk valves (Hiatella arctica) in growth position collected from a raised marine deposit $(15 \mathrm{~m}$ asl), about $5 \mathrm{~km}$ west of the Sermeq Kujalleq calving margin (Fig. 2A; Table 2). Although the shell has an unknown relationship to the marine limit, its age nonetheless places a minimum constraint on the deglaciation of the inner fjord.

\section{Naternaq}

We obtained five basal radiocarbon ages from four lakes from the Naternaq study area that provide minimum limiting constraints on deglaciation (Figs 2B and 3A; Table 2; for core descriptions see Appendix S2 and Fig. S1). Basal sediments from two isolation basins (informal names S3 and S4) located $5.5 \mathrm{~km}$ west of Nordenskiöld Gletscher and within the Fjord Stade Moraines (Fig. 3) yielded ages of $7970 \pm 40$ cal a BP (a marine bivalve fragment from S4) and $7470 \pm 40 \mathrm{cal}$ a BP (macrofossils from S3). Two lakes (one proglacial and one non-glacial) near the right-lateral flank of Nordenskiöld Gletscher were also cored (Fig. 3B). Cores from two basins in Pterodactyl Lake (proglacial) yielded ages from macrofossils of $7210 \pm 40$ and $7250 \pm 70 \mathrm{cal}$ a BP. A single core from a nearby Cab Lake (non-glacial) yielded a radiocarbon age on macrofossils of $7200 \pm 30 \mathrm{cal}$ a BP.

\section{Discussion}

\section{Late Pleistocene deglaciation in west Greenland}

The $18{ }^{10} \mathrm{Be}$ ages and five radiocarbon ages presented here provide constraints on the deglaciation of the GrIS in both marine- and land-based ice marginal settings (Figs 2 and 4). Our ${ }^{10} \mathrm{Be}$ ages from outer Torsukattak fjord (site T1) place ice retreat from Vaigat Strait and into Torsukattak fjord by $10.9 \pm 0.5 \mathrm{ka}$, and are $\sim 1000$ years older than previously published minimum limiting radiocarbon ages on deglaciation from the area (Fig. 2A; Tauber, 1960; Weidick, 1968; Long et al., 1999). The ${ }^{10} \mathrm{Be}$ ages demarcate the eastward retreat of the GrIS up Torsukattak fjord, indicating that the mid-fjord deglaciated at $10.3 \pm 0.5 \mathrm{ka}$ (site T2), and that the fjord head became ice-free at $10.0 \pm 0.2 \mathrm{ka}$ (site T3). Thinning 
Figure 3. Aerial photographs taken in 1985 showing lakes S3 and S4 (A) and Pterodactyl and Cab lakes (B), with coring locations (stars), ${ }^{10} \mathrm{Be}$ sample locations and the position of the Fjord Stade Moraines (crests as orange lines). Ice flow in the image was east to west. Inset in the upper right is a Landsat image showing the locations of $A$ and $\mathrm{B}$ of the enlarged area with reference to Nordenskiöld Gletscher. (For interpretation of the references to color in this figure legend, the reader is referred to the online version of this article.) This figure is available in colour online at wileyonlinelibrary.com.

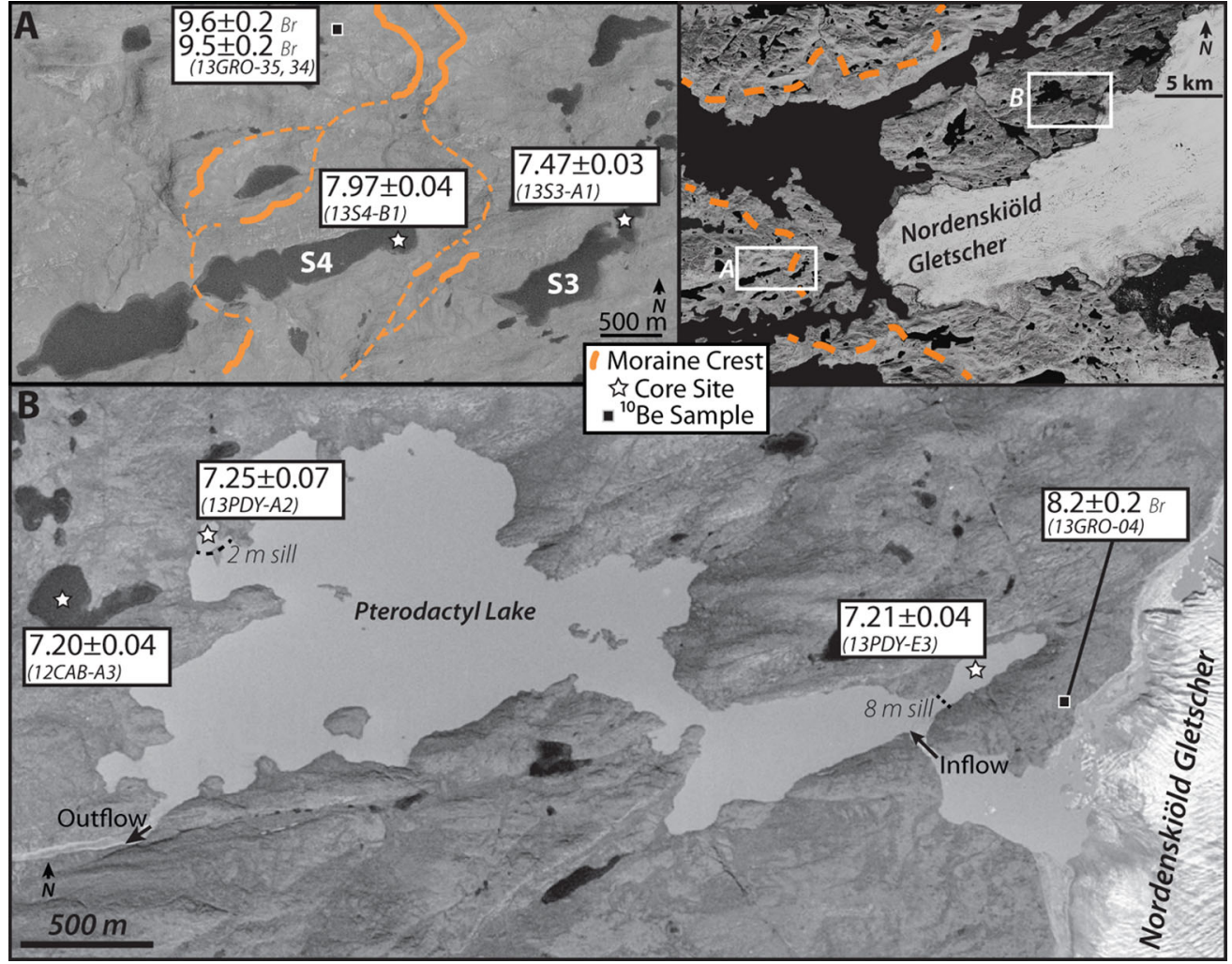

and retreat of the ice margin exposed a nunatak $\sim 10 \mathrm{~km}$ north-east of the present fjord head at $9.3 \pm 0.1 \mathrm{ka}$ (site T4). Our minimum-limiting radiocarbon age from the fjord head of $8260 \pm 60 \mathrm{cal}$ a BP is consistent with our ${ }^{10} \mathrm{Be}$ chronology.

Our ${ }^{10} \mathrm{Be}$ ages from the westernmost sites in the Naternaq study area, sites $\mathrm{N} 1$ and $\mathrm{N} 2$, constrain GrIS retreat onto land at $11.7 \pm 0.3 \mathrm{ka}(n=4 ;$ Fig. $2 \mathrm{~B})$. The GrlS continued eastward retreat, reaching site N3 at $11.1 \pm 0.4 \mathrm{ka}, \mathrm{N} 4$ at $10.0 \pm 0.3 \mathrm{ka}$ and $\mathrm{N} 5$ at $10.3 \pm 0.3 \mathrm{ka}$. Deglaciation continued eastward, with ages of $9.6 \pm 0.1 \mathrm{ka}$ at site N6, outboard of the Fjord Stade Moraines, and $8.3 \pm 0.2$ ka (site N7) inboard of the moraines. These ages are supported by minimum-limiting radiocarbon ages from lakes $\mathrm{S} 3$ and $\mathrm{S} 4$ of $7470 \pm 40$ and $7970 \pm 40 \mathrm{cal}$ a BP, respectively (Figs $2 \mathrm{~B}$ and $3 \mathrm{~A}$ ).

The easternmost ${ }^{10} \mathrm{Be}$ age in the study area of $8.2 \pm 0.2 \mathrm{ka}$ was obtained from site N8, $250 \mathrm{~m}$ north of the right-lateral flank of Nordenskiöld Gletscher, with two radiocarbon ages from a proglacial threshold lake, Pterodactyl Lake, placing the retreat of the GrIS from the lake's catchment at $7230 \pm 30 \mathrm{cal}$ a BP $(n=2)$. The difference between the ${ }^{10} \mathrm{Be}$ age from near the ice margin and radiocarbon ages from within Pterodactyl Lake allows a number of possible scenarios: (1) these ages indicate that GrIS meltwater drained into the Pterodactyl Lake catchment for as long as 1000 years after it retreated from site N8; (2) a significant lag exists between deglaciation registered by ${ }^{10} \mathrm{Be}$ ages and a change in sedimentation in the lakes due to local stagnant ice or unstable hill slopes; (3) there is significant error in one or all the ages. We feel that scenario 1 is unlikely given similarity in basal ages from the small-catchment Cab Lake and proglacial Pterodactyl Lake. Scenario 2 is plausible, as it is logical that some lag exists between a glacier exiting a catchment and a change from minerogenic to organic sedimentation. That said, a study from the Jakobshavn area documents a short-lived (decadal scale) advance and retreat of the GrIS in and out of a lake's catchment (Young et al., 2011b), suggesting that a lag in change of sedimentation of $\sim 1000$ years may be unlikely. Scenario 3 cannot be proven or disproven given the present information, although the radiocarbon ages from Nordenskiöld Gletscher are internally consistent $(n=3)$, and the ${ }^{10} \mathrm{Be}$ age is from a single sample.

\section{Fjord stade moraines}

The Fjord Stade Moraines form a prominent moraine belt that spans central West Greenland (Weidick, 1968; Funder et al., 2011). In the Disko Bugt region, the Fjord Stade Moraines have been precisely dated to correlate with the 9.3- and 8.2ka cold events (Young et al., 2011a). The ${ }^{10}$ Be ages from sites N6 and N7 bracket the deposition of the moraine between $9.6 \pm 0.1$ and $8.3 \pm 0.2 \mathrm{ka}$, confirming the earlier interpretation that they are part of the Fjord Stade Moraine system (Weidick and Bennike, 2007; Funder et al., 2011). A radiocarbon date from a mollusk fragment retrieved from lake core 13S4-B1 provides additional constraints on moraine deposition before $7970 \pm 40 \mathrm{cal}$ a BP. This chronology is consistent with the findings of Young et al. (2011a), implicating climate forcing for the deposition of the moraines (Kelly, 1985), rather than ice sheet dynamics controlled by topography and ice-stream dynamics (Warren and Hulton, 1990; Long et al., 2006).

\section{Disko Bugt retreat rates}

The deglacial chronologies reconstructed for the Torsukattak (marine-based) and Nordenskiöld (land-based) areas allow us to compare the retreat rates of the two contrasting ice margin settings (Fig. 4). We calculate maximum and minimum possible net retreat rates using the one-sigma ${ }^{10} \mathrm{Be}$ age ranges from our transects (for all information used in calculations see Supplementary Table S1). At Torsukattak fjord, the average ${ }^{10} \mathrm{Be}$ age at sites $\mathrm{T} 1$ and $\mathrm{T} 4$ are used to obtain a net retreat rate of $45 \pm 20 \mathrm{~m} \mathrm{a}^{-1}$. We acknowledge that as the elevations 
Table 2. Sample information for radiocarbon ages.

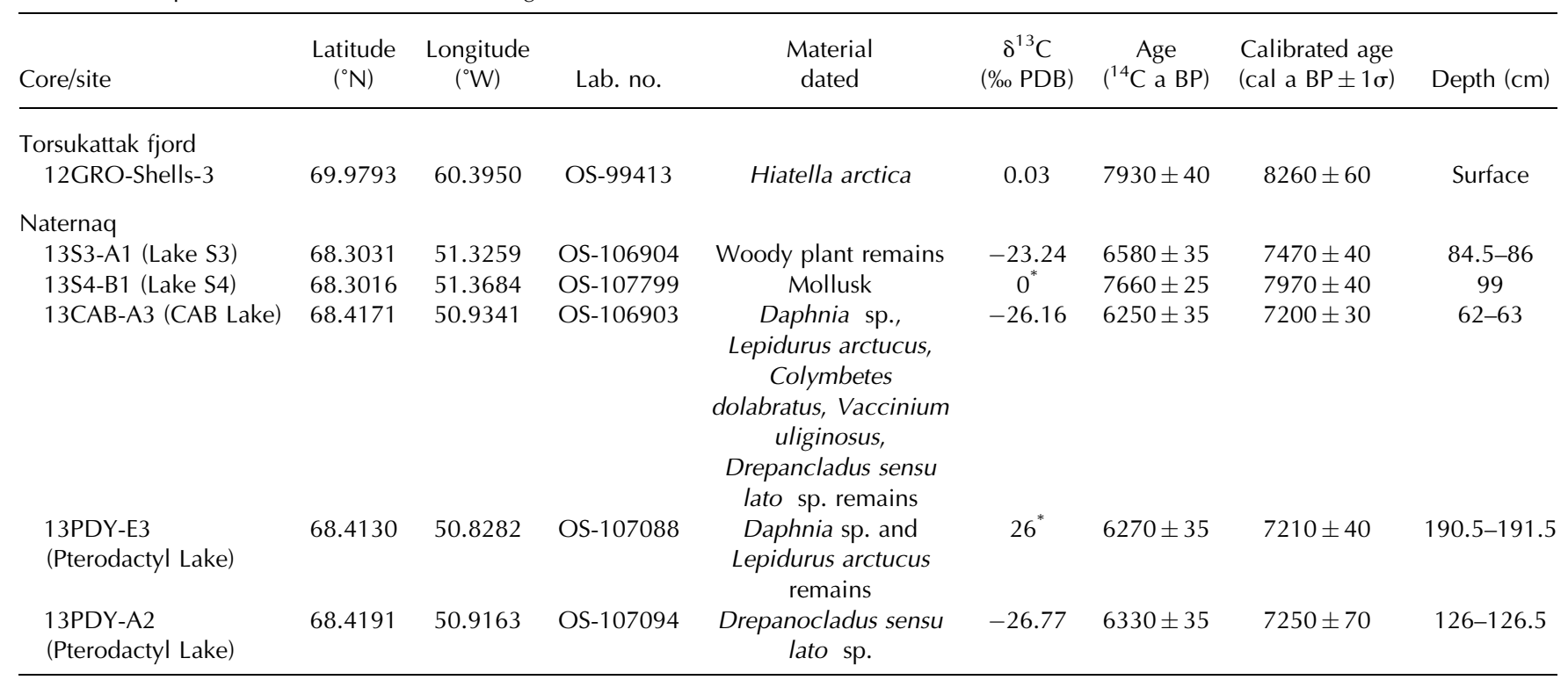

${ }^{*}$ Assumed $\delta{ }^{13} \mathrm{C}$ value.

of the ${ }^{10} \mathrm{Be}$ ages vary $(102-507 \mathrm{~m}$ asl), they are influenced by both thinning and retreat elements of ice margin change. We do not believe this has a major influence on retreat rate calculations that span millennia, and in fact modern observations document that vertical thinning and lateral retreat occur in tandem in similar settings to the north (Kjær et al., 2012). Regardless, unlike the transect at Torsukattak fjord, the transect within the Naternaq study area encompasses the Fjord Stade Moraines. The net rate of retreat over the entire transect (average age of sites N1 and N2 to site N7) is $25 \pm 5 \mathrm{~m} \mathrm{a}^{-1}$. The net retreat between the coast (average age of sites N1 and N2) and the Fjord Stade Moraines (site N6) is $40 \pm 10 \mathrm{~m} \mathrm{a}^{-1}$. Although both retreat rates calculated for the Nordenskiöld transect are within error of the Torsukattak transect, it may be more reasonable to compare the Torsukattak retreat rate with the coast-site N6 retreat rate from the Nordenskiöld transect, thus not including a stillstand or readvance in either transect.

The similar rates of retreat exhibited by the two sectors of the GrlS before $\sim 9 \mathrm{ka}$ is striking given the difference in ice margin setting. In marine-based glacier systems, ice dynamics, such as increasing calving rates due to fjord geometry changes, in addition to mass loss to ocean heat transport can play major roles in frontal ablation (Rignot et al., 2010; Carr et al., 2013; Enderlin et al., 2013). Previous work has documented the ability of marine-based glaciers to rapidly retreat in response to warming during the late Pleistocene (Briner et al., 2009; Hughes et al., 2012; Mangerud et al., 2013), as well as during contemporary periods (Scambos et al., 2004). Our results indicate that when averaged on millennial timescales, land-based glacier systems can retreat as quickly as their marine-based counterparts.

\section{West Greenland retreat rates}

We place our results into a wider context by calculating retreat rates for seven additional transects (nine total transects) along the West Greenland coast using previously published ${ }^{10}$ Be chronologies (Fig. 5; Bennike et al., 2011; Levy et al., 2012; Kelley et al., 2013; Roberts et al., 2013; Young et al., 2013a; Lane et al., 2014; Larsen et al., 2014). Transects for retreat rate calculations were constructed along estimated ice-sheet flow lines, and extend from the present ice margin to the western coastline of Greenland. In all locations where existing chronology allows, a transect mid-point was selected outboard of the Fjord Stade Moraines (using Weidick, 1968), which allows us to compare pre-Fjord Stade Moraine retreat rates. Net retreat rates were calculated for the entire transect

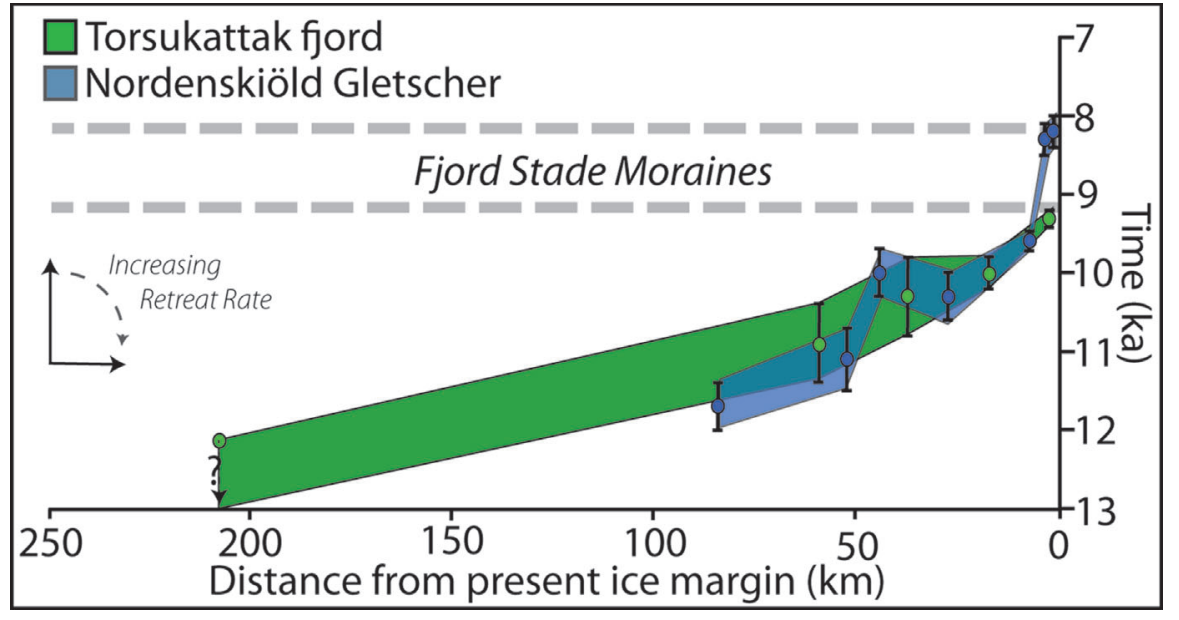

Figure 4. Time-distance diagram of the GrlS margin for four transects in the Disko Bugt region shown in Fig. $1 .{ }^{10} \mathrm{Be}$ age constraints for Torsukattak fjord and Nordenskiöld Gletscher from this study; where multiple ages exist at a single site, the average ( \pm one $\mathrm{SD}$ ) of the ages at a site is used. Note that the outermost site in the Torsukattak transect is a radiocarbon age (from Bennike et al., 1994), and thus is a minimum limiting constraint on deglaciation; all other ages are from ${ }^{10} \mathrm{Be}$ dating. This figure is available in colour online at wileyonlinelibrary.com. 


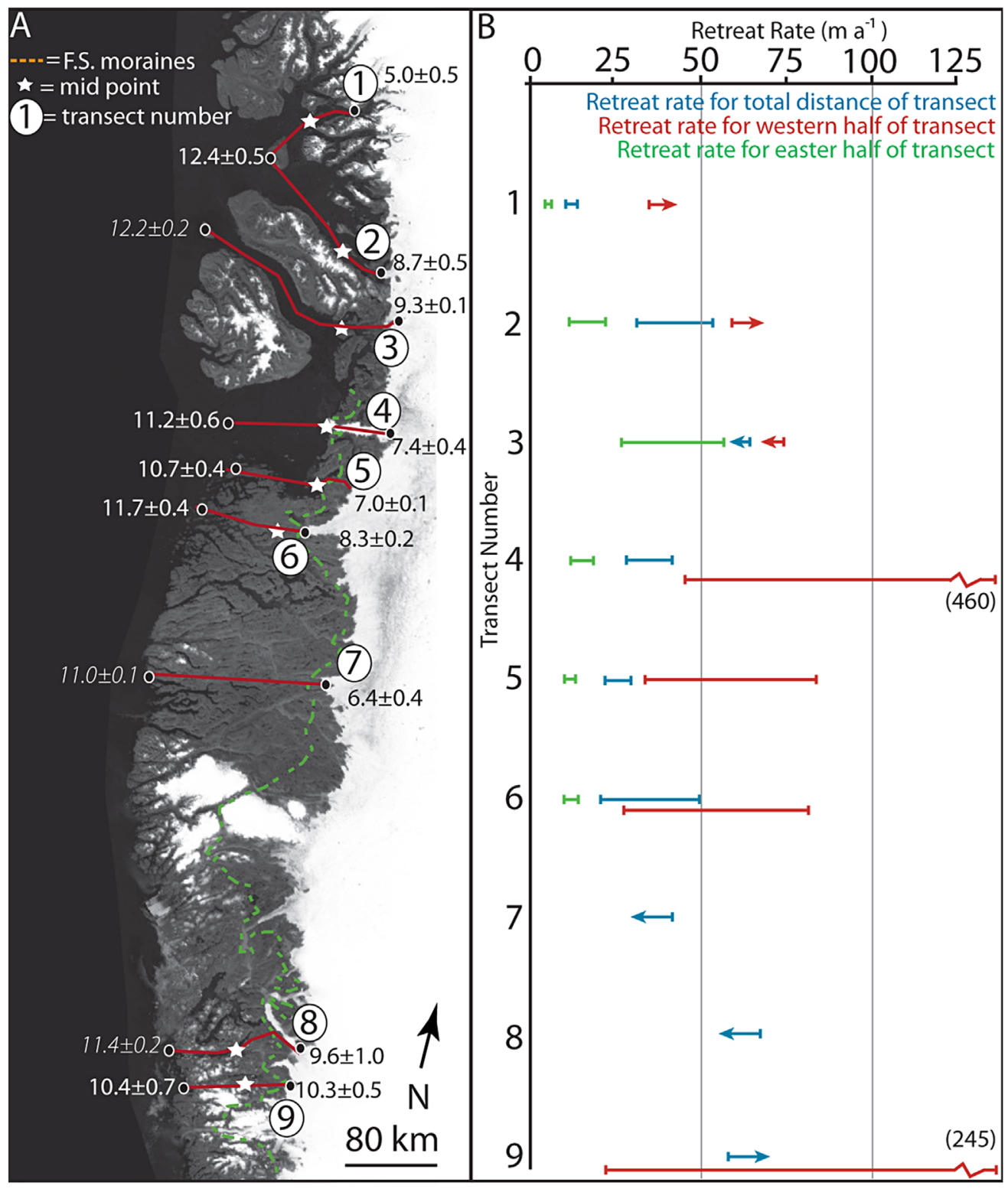

Figure 5. (A) Locations of transects used for calculation of net retreat rates in western Greenland: northern Uummannaq [transect 1; Lane et al. (2013); Roberts et al. (2013)]; southern Uummannaq [transect 2; Roberts et al. (2013)]; Vaigat Strait - Torsukattak fjord [transect 3; this study; Bennike et al. (1994)]; central Disko Bugt [transect 4; Kelley et al. (2013); Young et al. (2013a)]; southern Disko Bugt [transect 5; Kelley et al. (2013); Young et al. (2013a)]; Nordenskiöld Gletscher system [transect 6; this study]; Sisimiut [transect 7; Bennike et al. (2011); Levy et al. (2012)]; Godthåbsfjorden [transect 8; Larsen et al. (2014)]; Sermilik [transect 9; Larsen et al. (2014)]. Overlain on the map are ages (in ka \pm 1 SD) for the timing of GrIS retreat onto land and recession east of the present ice margin (radiocarbon ages in italic font, ${ }^{10} \mathrm{Be}$ ages in plain font). White stars indicate the transect's mid-point (none available for transect 7); orange dotted line denotes the position of the Fjord Stade Moraines from Weidick (1968) and Funder et al. (2011). (B) Retreat rate ranges calculated for transects in A. Blue bars indicate net retreat rate for the total transect, red bars denote net retreat rate for the westerly portion of the transect and green bars denote net retreat rate for the easterly portion of the transect. Arrows indicate maximum or minimum retreat rates. For all values used in retreat calculations see Table S1. (For interpretation of the references to color in this figure legend, the reader is referred to the online version of this article.) This figure is available in colour online at wileyonlinelibrary. com.

(from the western coast to the age nearest the present ice margin) for all transects, as well as for a pre-Fjord Stade Moraine subsection for some transects. In some localities where direct ${ }^{10} \mathrm{Be}$ age control is lacking, minimum-limiting radiocarbon ages were used (transects $3,7,8$ ). In these instances only maximum or minimum rates were calculated. Calculations from some transects yielded overlapping ages and therefore infinite retreat rates (transects 1, 2, 7, 8, 9); in these cases only minimum retreat rates are reported.

Two patterns emerge from the comparison of retreat rates along the western GrlS margin. First, net retreat rates for entire transects, which range from 10 to $>65 \mathrm{~m} \mathrm{a}^{-1}$, are generally similar, and often overlap within error, to those from our two transects near Disko Bugt (25-45 m a $\mathrm{a}^{-1}$; Fig. 5).
This similarity exists despite the high degree of variability in the ice margin setting (e.g. marine-based, land-based). For example, retreat rates from fjords such as southern Uummannaq or Torsukattak (eastern portion of transect 3, Fig. 5) are $40 \pm 10$ and $40 \pm 15 \mathrm{~m} \mathrm{a}^{-1}$, respectively, while retreat rates from land-based systems such as Nordenskiöld and Sisimiut overlap within error with their marine-based counterparts, with retreat rates of $35 \pm 5$ and $\leq 40 \mathrm{~m} \mathrm{a}^{-1}$, respectively (Fig. 5). This similarity in retreat rates along the western GrlS margin indicates that on millennial timescales, climate, rather than ice dynamics tied to ice marginal setting, seems to be the dominant factor controlling ice margin fluctuations.

The second pattern revealed through comparison of retreat rates is that retreat rates for the older, westerly portion of the 
transects are consistently higher than those calculated for the younger, easterly portion of the transects. In some cases, such as central Disko Bugt, the retreat rate is an order of magnitude higher in the west versus the east. Consistently lower retreat rates in the eastern portion of some transects are due, at least in part, to the fact that the eastern portion of transects encompass the deposition of the Fjord Stade Moraines, as mapped by Weidick (1968). The deposition of the Fjord Stade Moraines throughout West Greenland indicates that even short-lived climate events can elicit a uniform response of the ice sheet.

Farther abroad, retreat rates of $\geq 80 \mathrm{~m} \mathrm{a}^{-1}$ (Hughes et al., 2012), $>58 \mathrm{~m} \mathrm{a}^{-1}$ (Briner et al., 2009), $180 \mathrm{~m} \mathrm{a}^{-1}$ (Larter et al., 2014) and 240-370 $\mathrm{m} \mathrm{a}^{-1}$ (Mangerud et al., 2013) have been determined for deglaciation in other marine-based outlet glacier systems. In addition, a detailed study of retreat of numerous marine-based outlet glaciers of the Fennoscandian Ice Sheet reveal retreat rates similar to those in this study, with an average of $\sim 30 \mathrm{~m} \mathrm{a}^{-1}$ (Stokes et al., 2014). Land-based ice margin retreat has also been documented, with southern Laurentide Ice Sheet recession estimated to reach as high as $360 \mathrm{~m} \mathrm{a}^{-1}$ in central North America (Andrews, 1973; Dyke and Prest, 1987), and up to $300 \mathrm{~m} \mathrm{a}^{-1}$ along the south-eastern Laurentide Ice Sheet (Ridge et al., 2012). These examples document the ability of land-based portions of an ice sheet to retreat on pace with or faster than marine-based parts of ice sheet. This evidence supports our findings from Greenland that on millennial timescales, landbased sectors of ice sheets have the ability to retreat at rates equivalent to marine-based ice sheet sectors.

\section{Ice sheet response time}

Collectively, these results from millennial-scale records contrast with what is seen in the historical record, that marine-terminating outlet glaciers retreated more rapidly than land-based ice sheet sectors. Contemporary ice sheet retreat rates vary widely, with a mean glacier retreat recorded in south-east Greenland from AD 1992 to 2000 of $106 \mathrm{~m} \mathrm{a}^{-1}$ (Moon and Joughin, 2008), although rates $>1500 \mathrm{~m} \mathrm{a}^{-1}$ are calculated for portions of the Pine Island Glacier between AD 1996 and 2009 (Joughin et al., 2010). While contemporary ice sheet retreat rates are variable, the fastest retreating outlet glaciers in West Greenland appear to be dominantly marine-based during the past century (Kelley et al., 2012). The juxtaposition of our millennialscale records of net ice sheet retreat and more recent retreat rates suggests that time scale is key for understanding the difference between early Holocene retreat rates versus those in historical times, an important point for placing the present observations in context.

We believe that the similarity in retreat rates within our study indicates that climate is the dominant mechanism influencing early Holocene ice margin change. We believe that the ice margin was in equilibrium with climate on millennial or longer timescales due to the relatively synchronous response from the GrIS across such a broad area. However, on shorter timescales, such as the $\sim 170$-year historical record of ice margin fluctuation in West Greenland, a strong influence of ice dynamics creates asynchrony in the pattern of GrlS change. This indicates that the response time of the ice margin to changes in climate is variable on the centennial scale and that ice sheet response time to climate is probably $<1000$ years for all ice margin types. Brief periods with more rapid retreat may be a feature of our record as well: some segments of our transects demonstrate significantly higher rates on shorter time scales than the net retreat integrated over multiple millennia. For instance, retreat across central Disko Bugt may have been as high as $450 \mathrm{~m} \mathrm{a}^{-1}$ during the millennia or less that it took the GrIS to retreat across Disko Bugt. In addition, retreat of marine-based glaciers is well documented for the Fennoscandian Ice Sheet, where net retreat rates are $\sim 30 \mathrm{~m} \mathrm{a}^{-1}$ when averaged over multiple millennia, although periods of rapid retreat $\left(\sim 150 \mathrm{~m} \mathrm{a}^{-1}\right)$ occurred on shorter time scales (Stokes et al., 2014).

A large difference between the marine- and land-based glaciers is ice velocity. In a survey of 242 Greenland glaciers, the fastest 140 glaciers are marine-terminating, with marineterminating glaciers having a peak velocity an order of magnitude higher than land-terminating glaciers (Rignot and Mouginot, 2012). The perturbation theory proposed by Nye (1960) suggests that the local response time of a glacier is the inverse of the local velocity, and thus variability in velocity between ice margin sectors should create varying response times or sensitivity to changes in climatic forcing. Additional factors may enhance the sensitivity of marine-based outlet glaciers to climate change that do not apply to land-based glaciers, such as effects of calving, loss of floating tongues and melting along submarine ice fronts (van der Veen, 2001).

The dichotomy in the behavior of the GrlS outlet glaciers on millennial versus shorter timescales illustrates the varying response time of different glacier systems and the controls velocity may play on different timescales. Asynchronies in the behavior of differing ice margin sectors driven by varying response time of land- versus marine-based ice margins do not appear to be a significant feature in our reconstruction of retreat rates averaged over millennial timescales, while this feature is readily apparent in contemporary records. Therefore, predictions of future ice sheet change must reconcile lags of land-based ice margin sectors on sub-millennial scales, as well as account for the possibility of future retreat of the now stable sections of the ice margin when ice sheet behavior is examined over longer periods.

\section{Conclusions}

Our results demonstrate that the GrIS retreated through Torsukattak fjord between $\sim 10.9$ and $\sim 9.3 \mathrm{ka}$ at a rate of $45 \pm 20 \mathrm{~m} \mathrm{a}^{-1}$. The GrIS retreated from Baffin Bay onto land west of Nordenskiöld Gletscher at $\sim 11.7 \mathrm{ka}$, with retreat before Fjord Stade moraine deposition occurring at a rate of $40 \pm 10 \mathrm{~m} \mathrm{a}^{-1}$. The rate and timing of retreat of the two areas is similar, although the ice margin retreat occurred in a marine setting at one location and in a land-based setting in the other. A compilation of retreat rates from West Greenland demonstrates that net GrIS retreat occurred at rates of about 25 and $45 \mathrm{~m} \mathrm{a}^{-1}$, regardless of ice marginal environment. Thus, on millennial timescales, climate rather than dynamics related to ice marginal setting seems to be the dominant control on rate of retreat.

Our finding of synchronous retreat of the GrlS margin on millennial timescales is in contrast to historical observations of faster retreat of marine-terminating outlet glaciers compared with significantly slower retreat of land-based ice margin sectors. This dichotomy in behavior of the ice margin on millennial versus decadal/centennial timescales is probably due to response time of differing ice marginal settings with respect to climatic forcing. Our findings illustrate the ability of land-based sectors of the GrIS margin to retreat at rates comparable to marine-terminating glaciers. We conclude that any significant lag in the response of the GrIS to climate change, past or future, is limited to centennial or shorter timescales. 


\section{Supporting information}

Additional supporting information may be found in the online version of this article.

Appendix S1. Methodological detail of 10Be dating, radiocarbon sample preparation, and lake coring.

Appendix S2. Lake Physiography and Core Stratigraphy.

Figure S1. Sediment stratigraphy from the five lake cores collected from the Naternaq study area. Table S1. Data used in retreat rate calculations.

Table S1. Data used in retreat rate calculations..

Acknowledgements. We are grateful for laboratory assistance from Sylvia Choi and Matt McClellan, and field assistance from Sandra Cronauer. We thank Nicolaj Larsen and an anonymous reviewer for comments that improved the manuscript. This research was funded by grant NSF-1156361 from the US National Science Foundation Program of Geography and Spatial Science. This is LLNL-JRNL-665782

Abbreviations. GrIS, Greenland Ice Sheet; WGC, West Greenland Current.

\section{References}

Andrews 1973. The Wisconsin Laurentide Ice Sheet: dispersal centers, problems of rates of retreat, and climatic implications. Arctic and Alpine Research 5: 185-199.

Bennike O, Hansen KB, Knudsen KL et al. 1994. Quaternary marine stratigraphy and geochronology in central West Greenland. Boreas 23: 194-215.

Bennike O, Wagner B, Richter A. 2011. Relative sea level changes during the Holocene in the Sisimiut area, south-western Greenland. Journal of Quaternary Science 26: 353-361.

Bjørk AA, Kjær KH, Korsgaard NJ et al. 2012. An aerial view of 80 years of climate-related glacier fluctuations in southeast Greenland. Nature Geoscience 5: 427-432.

Box JE. 2002. Survey of Greenland instrumental temperature records: 1873- 2001. International Journal of Climatology 22: 1829-1847.

Briner JP, Bini AC, Anderson RS. 2009. Rapid early Holocene retreat of a Laurentide outlet glacier through an Arctic fjord. Nature Geoscience 2: 496-499.

Briner JP, Kaufman DS, Bennike O et al. 2014. Amino acid ratios in reworked marine bivalve shells constrain Greenland Ice Sheet history during the Holocene. Geology 42: 75-78.

Carr JR, Stokes CR, Vieli A. 2013. Recent progress in understanding marine-terminating Arctic outlet glacier response to climatic and oceanic forcing: twenty years of rapid change. Progress in Physical Geography 37: 436-467.

Donner J, Jungner H. 1975. Radiocarbon dating of shells from marine Holocene deposits in the Disko Bugt area, West Greenland. Boreas 4: 25-45.

Dyke AS, Prest VK. 1987. Late Wisconsinan and Holocene History of the Laurentide Ice Sheet. Geographie Physique et Quaternaire 41: 237-263.

Dyke LM, Hughes ALC, Murray T et al. 2014. Evidence for the asynchronous retreat of large outlet glaciers in southeast Greenland at the end of the last glaciation. Quaternary Science Reviews 99: $244-259$.

Enderlin EM, Howat IM, Vieli A. 2013. High sensitivity of tidewater outlet glacier dynamics to shape. Cryosphere Discussions 7: 551572.

Frich P, Ingólfsson O. 1990. Det holocæene sedimentationsmiljø ved Igpik samt en model for den relative landhævning i Disko Bugt området, Vestgrønland. AÊErsskrift for Dansk Geologisk Forening 1987 89: $1-10$.

Funder S, Kjeldsen KK, Kjær KH et al. 2011. The Greenland Ice Sheet during the past 300, 000 years: a review. In Elhers J, Gibbard PL (eds). Quaternary glaciations-extent and chronology. Elsevier Science: Amsterdam 15: 699-713.

Hogan KA, Dowdeswell JA, Ó Cofaigh C et al. 2012. Glacimarine sedimentary processes and depositional environments in an embayment fed by West Greenland ice streams. Marine Geology 311-314: 1-16.

Holland DM, Thomas RH, De Young B et al. 2008. Acceleration of Jakobshavn Isbræ triggered by warm subsurface ocean waters. Nature Geoscience 1: 659-664.

Hughes ALC, Rainsley E, Murray T et al. 2012. Rapid response of Helheim Glacier, southeast Greenland, to early Holocene climate warming. Geology 40: 427-430.

Ingólfsson Ó, Frich P, Funder S et al. 1990. Paleoclimatic implications of an early Holocene glacier advance on Disko island, West Greenland. Boreas 19: 297-311.

Jennings AE, Walton ME, Ó Cofaigh C et al. 2014. Paleoenvironments during Younger Dryas-Early Holocene retreat of the Greenland ice sheet from outer Disko trough, central west Greenland. Journal of Quaternary Science 29: 27-40.

Joughin I, Smith BE, Holland DM. 2010. Sensitivity of 21st century sea level to ocean-induced thinning of Pine Island Glacier, Antarctica. Geophysical Research Letters 37: L200502.

Kelley SE, Briner JP, Young NE et al. 2012. Maximum Late Holocene extent of the western Greenland Ice Sheet during the late 20th century. Quaternary Science Reviews 56: 89-98.

Kelley SE, Briner JP, Young NE. 2013. Rapid ice retreat in Disko Bugt supported by ${ }^{10}$ Be dating of the last recession of the western Greenland Ice Sheet. Quaternary Science Reviews 82: 13-22.

Kelly M. 1985. A review of the Quaternary geology of western Greenland. In Quaternary Environments; Eastern Canadian Arctic, Baffin Bay and Western Greenland, Andrews JT (ed.). London: Allen \& Unwin. pp. 461-501.

Khan SA, Kjær KH, Bevis M et al. 2014. Sustained mass loss of the northeast Greenland ice sheet triggered by regional warming. Nature Climate Change 4: 292-299.

Kjær KH, Khan SA, Korsgaard NJ et al. 2012. Aerial photographs reveal late-20th-century dynamic ice loss in northwestern Greenland. Science 337: 569-573.

Lal D. 1991. Cosmic ray labeling of erosion surfaces: in situ nuclide production rates and erosion models. Earth and Planetary Science Letters 104: 424-439.

Lane TP, Roberts DH, Rea BR et al. 2014. Controls upon the Last Glacial Maximum deglaciation of the northern Uummannaq Ice Stream System, West Greenland. Quaternary Science Reviews 92: 324-344.

Larsen NK, Funder S, Kjær KH et al. 2014. Rapid early Holocene ice retreat in West Greenland. Quaternary Science Reviews 92: 310323.

Larter RD, Anderson JB, Graham AGC et al. 2014. Reconstruction of changes in the Amundsen Sea and Bellingshausen Sea sector of the West Antarctic Ice Sheet since the Last Glacial Maximum. Quaternary Science Reviews 100: 55-86.

Levy LB, Kelly MA, Howley JA et al. 2012. Age of the Ørkendalen moraines, Kangerlussuaq, Greenland: constraints on the extent of the southwestern margin of the Greenland Ice Sheet during the Holocene. Quaternary Science Reviews 52: 1-5.

Lloyd J, Moros M, Perner K et al. 2011. A 100 yr record of ocean temperature control on the stability of Jakobshavn Isbrae, West Greenland. Geology 39: 867-870.

Lloyd J, Park L, Kuijpers A et al. 2005. Early Holocene palaeoceanography and deglacial chronology of Disko Bugt, west Greenland. Quaternary Science Reviews 24: 1741-1755.

Long AJ, Roberts DH. 2002. A revised chronology for the 'Fjord Stade'moraine in Disko Bugt, west Greenland. Journal of Quaternary Science 17: 561-579.

Long AJ, Woodroffe SA, Roberts DH et al. 2011. Isolation basins, sealevel changes and the Holocene history of the Greenland Ice Sheet. Quaternary Science Reviews 30: 3748-3768.

Long AJ, Roberts DH, Dawson S. 2006. Early Holocene history of the west Greenland Ice Sheet and the GH-8.2 event. Quaternary Science Reviews 25: 904-922.

Long AJ, Roberts DH, Rasch M. 2003. New observations on the relative sea level and deglacial history of Greenland from Innaarsuit, Disko Bugt. Quaternary Research 60: 162-171.

Long AJ, Roberts DH, Wright MR. 1999. Isolation basin stratigraphy and Holocene relative sea-level change on Arveprinsen Ejland, 
Disko Bugt, West Greenland. Journal of Quaternary Science 14: 323-345.

Mangerud J, Goehring BM, Lohne ØS et al. 2013. Collapse of marine-based outlet glaciers from the Scandinavian Ice Sheet. Quaternary Science Reviews 67: 8-16.

Möller P, Larsen NK, Kjær KH et al. 2010. Early to middle Holocene valley glaciations on northernmost Greenland. Quaternary Science Reviews 29: 3379-3398.

Moon T, Joughin I. 2008. Changes in ice front position on Greenland's outlet glaciers from 1992 to 2007. Journal of Geophysical Research 113: n F2.

Nye JF. 1960. The response of glaciers and ice-sheets to seasonal and climatic changes. Proceedings of the Royal Society of London. Series A. Mathematical and Physical Sciences 256: 559-584.

O Cofaigh C, Dowdeswell JA, Jennings AE et al. 2013. An extensive and dynamic ice sheet on the West Greenland shelf during the last glacial cycle. Geology 41: 219-222.

Quillmann U, Andrews JT, Jennings AE. 2009. Radiocarbon dates from marine sediment cores of the Iceland, Greenland, and northeast Canadian Arctic shelves and Nares Strait. Institute of Arctic and Alpine Research Occasional Paper 59: 14-15.

Ridge JC, Balco G, Bayless RL et al. 2012. The new North American varve chronology: A precise record of southeastern Laurentide Ice Sheet deglaciation and climate, 18. 2-12. $5 \mathrm{kyr} \mathrm{BP}$, and correlations with Greenland ice core records. American Journal of Science 312: 685-722.

Rignot E, Koppes M, Velicogna I. 2010. Rapid submarine melting of the calving faces of West Greenland glaciers. Nature Geoscience 3: 187-191.

Rignot E, Mouginot J. 2012. Ice flow in Greenland for the international polar year 2008-2009. Geophysical Research Letters 39: doi: 10.1029/2012GL051634.

Rinterknecht V, Jomelli V, Brunstein D et al. 2014. Unstable ice stream in Greenland during the Younger Dryas cold event. Geology 42: 759-762.

Roberts DH, Rea BR, Lane TP et al. 2013. New constraints on Greenland ice sheet dynamics during the last glacial cycle: evidence from the Uummannaq ice stream system. Journal of Geophysical Research: Earth Surface 118: 519-541.

Scambos TA, Bohlander J, Shuman C et al. 2004. Glacier acceleration and thinning after ice shelf collapse in the Larsen B embayment, Antarctica. Geophysical Research Letters 31: L18402.

Seidenkrantz M.-S, Roncaglia L, Fischel A et al. 2008. Variable North Atlantic climate seesaw patterns documented by a late Holocene marine record from Disko Bugt, West Greenland. Marine Micropaleontology 68: 66-83.
Stokes CR, Corner GD, Winsborrow MCM. et al. 2014. Asynchronous response of marine-terminating outlet glaciers during deglaciation of the Fennoscandian Ice Sheet. Geology 42: 455-458.

Stone JO. 2000. Air pressure and cosmogenic isotope production. Journal of Geophysical Research 105: 23753-23759.

Tauber H. 1960. Copenhagen radiocarbon dates IV. American lournal of Science: Radiocarbon Supplement 6: 215-225.

van der Veen CJ. 2001. Greenland ice sheet response to external forcing. Journal of Geophysical Research: Atmospheres 106: 34047-34058.

Vinther BM, Buchardt SL, Clausen HB. et al. 2009. Holocene thinning of the Greenland ice sheet. Nature 461: 385-388.

Warren C, Hulton N. 1990. Topographic and glaciological controls on Holocene ice-sheet margin dynamics, central West Greenland. Annals of Glaciology 14: 307-310.

Weidick A. 1968. Observations on some Holocene glacier fluctuations in west Greenland. Meddelesser om Grønland 165: 202.

Weidick A. 1974. Quaternary map of Greenland, 1 : 500,000 Sheet 3, Søndre Strømfjord-NÛgssuaq Kvartærgeologisk. Copenhagen: Greenland Geologic Survey.

Weidick A. 1994. Historical fluctuations of calving glaciers in south and West Greenland. Rapport Grønlands Geologiske Undersølgelse 161: 73-79.

Weidick A, Bennike, O. 2007. Quaternary glaciation history and glaciology of Jakobshavn Isbræ and the Disko Bugt region, West Greenland: a review. Copenhagen: Geological Survey of Denmark and Greenland.

Weidick A, Bennike O, Citterio M. et al. 2012. Neoglacial and historical glacier changes around Kangersuneq fjord in southern West Greenland. Copenhagen: Geological Survey of Denmark and Greenland.

Young NE, Briner JP, Axford $Y$ et al. 2011a. Response of a marineterminating Greenland outlet glacier to abrupt cooling 8200 and 9300 years ago. Geophysical Research Letters 38: L24701.

Young NE, Briner JP, Rood DH et al. 2013a. Age of the Fjord Stade moraines in the Disko Bugt region, western Greenland, and the 9.3 and 8.2 ka cooling events. Quaternary Science Reviews 60: 76-90.

Young NE, Briner JP, Stewart HAM. et al. 2011b. Response of Jakobshavn Isbræ, Greenland, to Holocene climate change. Geology 39: 131-134.

Young NE, Schaefer JM, Briner JP et al. 2013b. A ${ }^{10}$ Be productionrate calibration for the Arctic. Journal of Quaternary Science 28: $515-526$.

Zwally HJ, Abdalati W, Herring T. et al. 2002. Surface melt-induced acceleration of Greenland ice-sheet flow. Science 297: 218-222. 